\title{
Thermosensitive Antibiotic Resistance Plasmids in Enterobacteria
}

\author{
By H. WILLIAMS SMITH, Z. PARSELL AND P. GREEN \\ Houghton Poultry Research Station, Houghton, Huntingdon, \\ Cambridgeshire, PE17 2DA
}

(Received 22 March 1978)

Of 775 conjugative plasmids found in enterobacteria mediating antibiotic resistance, 24 $(3 \cdot 1 \%)$ were thermosensitive (ts); they were most common in Klebsiella pneumonice. Ts plasmids were also found in all the samples of sewage and river water examined. Over half of 73 ts plasmids from unrelated sources mediated resistance to chloramphenicol in addition to several other antibiotics. Many of them mediated resistance to mercury $(53.4 \%)$, arsenite $(38.4 \%)$ and tellurite $(79.5 \%)$ but not to copper, cobalt and silver. Fifty-eight belonged to incompatibility group $\mathrm{H} 2$ and 12 belonged to the $\mathrm{H} 1$ group. Resistance to mercury, arsenite and tellurite was common in strains containing $\mathrm{H} 2$ plasmids but not in $\mathrm{H} 1$ plasmids. The 73 plasmids transferred at high rates at 22 and $28^{\circ} \mathrm{C}$ and at lower rates at $15^{\circ} \mathrm{C}$; they transferred at very low rates or not at all at $37^{\circ} \mathrm{C}$. They could be divided into two sets according to whether they transferred at a high or at a low rate at $33{ }^{\circ} \mathrm{C}$. Unlike the prototype plasmid, Rts 1 , they were solely or mainly ts for transfer and not for replication and only one of them brought about a marked reduction in growth rate of its host organism at $42{ }^{\circ} \mathrm{C}$. None of the 73 plasmids mediated colicin or haemolysin production. Three plasmids, all from $K$. pneumoniae, mediated utilization of lactose, two of sucrose and raffinose and three, all belonging to group $\mathrm{H} 1$, of citrate. None of the plasmids increased the pathogenicity of Salmonella typhimurium for chicks or Escherichia coli $\mathrm{k} 12$ for mice.

\section{INTRODUCTION}

Enterobacteria harbouring chloramphenicol resistance plasmids have been present in the human environment for a considerable time, at least since the antibiotic came into clinical use some 25 years ago. Although many of them can transmit their resistance to Salmonella typhi at high rates in vitro (Smith, 1973), no outbreaks of chloramphenicol-resistant S. typhi infection in human beings were reported until 1972-3 when a large outbreak occurred in Mexico. It was soon followed by others in India, Vietnam and Thailand. The resistance of the strains responsible for these outbreaks, which was plasmid-borne, was principally to tetracycline, streptomycin, spectinomycin and sulphonamide in addition to chloramphenicol. The available evidence revealed that the Mexican outbreak was caused by a single strain of $S$. typhi as was the Indian outbreak, but those in Vietnam and Thailand were caused by at least nine Vi-types of $S$. typhi (Anderson, 1975). Each of these types would have acquired the plasmid determining its antibiotic resistance in a separate event, probably from nonpathogenic enterobacteria. There is no reason to believe that they had acquired the plasmid directly from each other.

Plasmids examined from all four outbreaks were thermosensitive (ts) in that they transferred at high rates at low temperatures, such as 22 and $28{ }^{\circ} \mathrm{C}$, but at very low rates or not at all at $37^{\circ} \mathrm{C}$ (Smith, 1974). They belonged to incompatibility group H1. Plasmids of this group, also ts but determining resistance to antibiotics other than chloramphenicol, have also been found in Salmonella typhimurium strains isolated in a number of countries 
including Britain (Anderson, 1975). Ts plasmids belonging to groups other than $\mathrm{H} 1$, or whose compatibility status has not been determined, have been reported by other workers (Terawaki et al., 1967; Coetzee et al., 1972; Yoshida et al., 1974; Grabow et al., 1975; Rodriguez-Lemoine et al., 1975; Sato et al., 1974; Smith \& Parsell, 1975). The prototype, Rts 1 (Terawaki et al., 1967), which has been intensively studied, determines kanamycin resistance in a strain of Proteus vulgaris. Its transfer frequency at $25^{\circ} \mathrm{C}$ is about $10^{5}$ times that at $37^{\circ} \mathrm{C}$. It is spontaneously eliminated from host cells at $42^{\circ} \mathrm{C}$ but not at $37^{\circ} \mathrm{C}$, and for that reason its thermosensitivity is ascribed to replication failure. Cultures of Rts $1^{+}$ Escherichia coli also grow poorly at $42{ }^{\circ} \mathrm{C}$, especially in broth containing $0.03 \%$ sodium lauryl sulphate (Terawaki et al., 1975). The other ts plasmids have been studied less closely but it is known, for example, that unlike Rts 1 some are thermosensitive for transfer rather than for replication.

Because of the suggestion implicit in the pattern of the chloramphenicol-resistant S. typhi outbreaks that ts antibiotic resistance plasmids might have become more prevalent in recent years, it was decided to study the distribution of these plasmids, especially those belonging to group $\mathrm{H} 1$, in the environment and their more important characteristics. Special attention was paid to their incidence in sewage and polluted rivers because, as they are thermosensitive, the distinct possibility exists that pathogenic enterobacteria would be more likely to acquire such plasmids in these locations than in the alimentary tract.

\section{METHODS}

Plasmids. Only plasmids possessing antibiotic resistance determinants were studied; their origin is given in Table 1. Those that transferred at very low rates, or not at all, at $37^{\circ} \mathrm{C}$ and at much higher rates at $28^{\circ} \mathrm{C}$ and/or $22{ }^{\circ} \mathrm{C}$ were designated thermosensitive (ts) and those that transferred at least as well at $37^{\circ} \mathrm{C}$ as at $28{ }^{\circ} \mathrm{C}$ or $22^{\circ} \mathrm{C}$ were designated thermotolerant (tt). Unless stated otherwise, their bacterial host in all experiments was a $l a c^{+}$prototrophic strain of Escherichia coli $\mathrm{k} 12$ called $\mathrm{K} 12$ Proto.

Bacterial strains. Those examined for ts plasmids were believed to be epidemiologically unrelated. They had been maintained in this laboratory for at least 1 year on Dorset egg medium at $5{ }^{\circ} \mathrm{C}$. A rough plasmidfree Salmonella typhimurium strain of phage type 36 was used as plasmid recipient during one stage of the isolation of plasmids from sewage and river water but in all other plasmid transfer studies a lac pro his trp phe strain of $E$. coli $\mathrm{x} 12$ called $\mathrm{K} 12$ Auxo was used. Both of these strains were spontaneous chromosomal mutants resistant to sodium nalidixate $\left(\mathrm{Nal}^{\mathrm{r}}\right)$ and rifampicin $\left(\mathrm{Rif}^{\mathrm{r}}\right)$.

Cultural conditions. Unless stated otherwise, bacteria were grown in $10 \mathrm{ml}$ nutrient broth (Oxoid, no. 2) for $24 \mathrm{~h}$ in a stationary water bath. Cultures on solid media were incubated for the same period in an air incubator.

Identification of strains possessing ts plasmids: the determination of plasmid transfer rate. Nutrient broth, pre-heated to $37^{\circ} \mathrm{C}$, was inoculated with $2 \mathrm{ml}$ of a broth culture of an antibiotic-resistant strain and $2 \mathrm{ml}$ of the $\mathrm{k} 12$ Auxo strain, both of which had been incubated at $37^{\circ} \mathrm{C}$. After incubation at this temperature, $0.1 \mathrm{ml}$ of the mating mixture was inoculated in a uniformly reproducible manner on to a plate of MacConkey agar containing sodium nalidixate and one of the antibiotics to which the donor strain was resistant (each at $20 \mu \mathrm{g} \mathrm{ml}^{-1}$ ). The plate was incubated at $37^{\circ} \mathrm{C}$ and the degree of bacterial growth upon it was taken as an indicator of the amount of plasmid transfer that had occurred. The transfer that occurred at $28{ }^{\circ} \mathrm{C}$ and at $22^{\circ} \mathrm{C}$ was assessed in the same manner except that all the broth cultures were incubated at these temperatures instead of at $37^{\circ} \mathrm{C}$. On the basis of these results, plasmids were provisionally classified as ts or tt.

The rate of plasmid transfer at different temperatures was assessed using a similar procedure. The total numbers of viable $\mathrm{K} 12$ Auxo organisms in the different mating mixtures were determined by a modification of the method of Miles \& Misra (1938) using MacConkey medium containing sodium nalidixate, and the numbers that had acquired the plasmid of the donor strain were determined by duplicate counts on similar medium with an additional antibiotic to which the plasmid provided resistance. The dilution procedures were performed rapidly in phosphate buffer at $5^{\circ} \mathrm{C}$ and the culture plates were pre-heated to $37^{\circ} \mathrm{C}$.

Sewage and river water. Specimens of untreated sewage were obtained on different occasions from sewage works in Essex and Cambridgeshire. River water was obtained from rivers in Essex, The Midlands and South Wales that were known to be polluted. Apart from those from the Welsh rivers, all specimens were examined within a few hours of collection.

Isolation of ts plasmids from sewage and river water. (1) Direct method. Specimens were filtered through 
butter muslin, centrifuged at $2500 \mathrm{~g}$ for $30 \mathrm{~min}$ and the deposit was inoculated in a manner likely to yield well-separated colonies on to five plates of MacConkey agar, each plate containing a different antibiotic (ampicillin, chloramphenicol, neomycin, streptomycin or tetracycline) at $20 \mu \mathrm{g} \mathrm{ml}^{-1}$. After incubation at $37^{\circ} \mathrm{C}$, up to 20 colonies from each plate were purified by replating on plain MacConkey agar and broth cultures were then examined for ts plasmids.

(2) Enrichment method. The centrifuged deposit from 11 sewage or river water that had been filtered through butter muslin was divided into five aliquots and each aliquot was incubated at $37^{\circ} \mathrm{C}$ in $20 \mathrm{ml}$ MacConkey broth (Oxoid, CM5) containing novobiocin $\left(10 \mu \mathrm{g} \mathrm{m}^{-1}\right)$ and one of each of the five antibiotics ( $30 \mu \mathrm{g} \mathrm{ml}^{-1}$ ) used in the direct method. The centrifuged deposit of each of these cultures was added to $10 \mathrm{ml}$ nutrient broth which had been inoculated with $2 \mathrm{ml}$ of a broth culture of the $S$. typhimurium strain. After incubation at $22^{\circ} \mathrm{C}$, each of the five cultures was inoculated on to plates of MacConkey agar containing sodium nalidixate and the antibiotic with which it had previously been grown (each at $20 \mu \mathrm{g} \mathrm{m}^{-1}$ ). Ten $S$. typhimurium colonies were picked from each plate, purified by replating and examined for ts plasmids. The $S$. typhimurium strain had been chosen for use in this method because it was much less susceptible than $E$. coli $\mathrm{K} 12$, for example, to the activity of phages and bacteriocins that were commonly present in the specimens of sewage and river water.

Whether obtained by the direct or the enrichment method, only one plasmid determining any particular antibiotic resistance pattern was retained from any one specimen of sewage or river water for further study; it was implanted in $\mathrm{K} 12$ Proto for this purpose.

Stability of plasmids at different temperatures. Approximately $10^{3}$ viable organisms of a plasmid-containing $\left(\mathrm{R}^{+}\right) \mathrm{K} 12$ Proto strain were inoculated into nutrient broth and each culture was incubated at a different temperature. Every $24 \mathrm{~h}$ a similar number of organisms was transferred from each culture to fresh broth at the same temperature and incubation was continued. At intervals, the cultures were replica-plated (Lederberg \& Lederberg, 1952) on to MacConkey agar with or without one of the antibiotics $\left(20 \mu \mathrm{g} \mathrm{ml}^{-1}\right)$ against which the plasmid provided resistance and the proportion of $R^{-} / \mathbf{R}^{+}$colonies was assessed.

Growth rate of $R^{+} \mathrm{K} 12$ Proto strains at $42^{\circ} \mathrm{C}$. This was studied by the method of Terawaki et al. (1975) employing Penassay broth (PAB, Difco) with or without $0.03 \%(\mathrm{w} / \mathrm{v})$ sodium lauryl sulphate. Bacterial growth rates were estimated by viable counts and by photometric methods.

Identification of $\mathrm{H} 1$ and $\mathrm{H} 2$ plasmids. Plasmids were designated $\mathrm{H} 1$ or $\mathrm{H} 2$ solely on their compatibility properties. They were first screened by the rapid test of Anderson (1975) and were designated $\mathrm{H1}$ if they were incompatible with $\mathrm{F}$ and with prototype $\mathrm{H} 1$ plasmids, and $\mathrm{H} 2$ if they were compatible with $\mathrm{F}$ and incompatible with the $\mathrm{H} 1$ prototypes. No measurements of molecular weight or percentage homology were made (Anderson, 1975). Compatibility was tested as described by Datta \& Olarte (1974).

Antibiotic sensitivity tests. These were done on Sensitest agar (Oxoid) by the disc method (Smith, 1977) using discs containing $25 \mu \mathrm{g}$ ampicillin (Ap), $50 \mu \mathrm{g}$ chloramphenicol $(\mathrm{Cm}), 30 \mu \mathrm{g}$ neomycin $(\mathrm{Nm}), 300$ units polymyxin, $25 \mu \mathrm{g}$ rifampicin, $25 \mu \mathrm{g}$ spectinomycin (Spc), $25 \mu \mathrm{g}$ streptomycin $(\mathrm{Sm}), 50 \mu \mathrm{g}$ tetracycline (Tc), $15 \mu \mathrm{g}$ furazolidone, $30 \mu \mathrm{g}$ sodium nalidixate, $300 \mu \mathrm{g}$ sulphonamides $(\mathrm{Su})$ and $1.25 \mu \mathrm{g}$ trimethoprim.

Identification of plasmids providing resistance to inorganic compounds. The plasmids were tested in the usual host organism, 12 Proto, except that they were tested against sodium arsenite in the $S$. typhimurium strain, as strain $\mathrm{k} 12$ Proto and all the other $\mathrm{K} 12$ strains available in this laboratory were moderately resistant to sodium arsenite. Broth cultures of the $\mathrm{R}^{+}$organisms and of the $\mathbf{R}^{-}$host organism, diluted 100 -fold, were streaked on plates of culture medium at right angles to strips of filter paper that had been soaked in aqueous solutions of copper sulphate $(5 \%, \mathrm{w} / \mathrm{v})$, cobalt sulphate $(5 \%, \mathrm{w} / \mathrm{v})$, sodium arsenite $(1 \%, \mathrm{w} / \mathrm{v})$, mercuric chloride $(0.1 \%, \mathrm{w} / \mathrm{v})$, silver nitrate $(0.1 \%, \mathrm{w} / \mathrm{v})$ and potassium tellurite $(0.01 \%, \mathrm{w} / \mathrm{v})$. The plates were incubated at $37^{\circ} \mathrm{C}$ and the relative susceptibility of the cultures was assessed by measuring the zones of inhibition of bacterial growth. The culture medium used for the silver nitrate tests was TYE agar (McHugh et al., 1975) and for the other tests was Sensitest agar.

Minimum inhibitory concentrations were determined by spot-inoculating a series of plates of Sensitest agar containing twofold differences in concentration of the substance under test with broth cultures of different $\mathrm{R}^{+}$organisms suitably diluted so that each spot contained approximately 200 viable organisms. The plates were incubated at $37^{\circ} \mathrm{C}$ and the lowest concentration that prevented visible growth was recorded as the minimum inhibitory concentration.

Colicinogenicity and lysogenicity tests. To identify colicinogenic strains, broth cultures were spot-inoculated on to plates of tryptose agar (Difco) that had been inoculated with 'lawns' of K12 Auxo and of the $S$. typhimurium strain. The plates were observed after incubation at $37^{\circ} \mathrm{C}$. The technique of identifying lysogenic strains was similar except that the culture medium was supplemented with sodium nalidixate $(20 \mu \mathrm{g}$ $\mathrm{ml}^{-1}$ ) and the strains were tested as supernates of centrifuged broth cultures.

Biochemical tests. These were done by the methods described by Cruickshank (1970); Elek's medium was used to detect urease production and Koser's liquid citrate medium $(5 \mathrm{ml})$ to detect citrate utilization, the 
Table 1. Presence of ts plasmids in $R^{+}$enterobacteria from different sources and in sewage and river water samples

No. of strains or

Material examined

$\mathrm{R}^{+}$Escherichia coli strains from man and animals

$\mathrm{R}^{+}$Klebsiella pneumoniae strains from animals

$\mathbf{R}^{+}$Salmonella strains from man and animals $\mathrm{R}^{+}$Shigella flexneri strains from man $\mathrm{R}^{+}$enterobacterial strains $\uparrow$ from rivers

$\mathbf{R}^{+}$enterobacterial strains $\uparrow$ from sewage plants

Samples of water: from 23 rivers

Samples of water: from 5 sewage plants samples examined 355 8 18 2 28 11

No. fo
9
3
1
0
9
2
32

1

0

9

2

32

17 ts plasmids

$\mathrm{Ap}$
$\mathrm{SmSuCmTcSpc}$

SmSuCmTcSpcNm (1)

SmSuCmTcAp (1)

$\mathrm{SmSuCmSpc}$

$\mathrm{SmCmTc}$

Tc

Ap (1)

$\mathrm{SmSuCmTcSpc}$ (2)

$\mathrm{SmSuCmSpc}$

$\mathrm{SmSuCm}$

ApSm

$\mathrm{SmSuCmTcSpc}$ (1)

$\mathrm{SmSuCmSpc}$

\begin{tabular}{|c|c|c|}
\hline $\mathrm{SmSuCmTcNm}$ & $\mathrm{pp} A$ & \\
\hline $\mathrm{SmSuCmTcSpcl}$ & $\sqrt{\mathrm{m}}$ & \\
\hline $\mathrm{SmSuCmTcSpc}$ & & \\
\hline SmSuCmSpc & & \\
\hline SmSuTcSpc & & \\
\hline SmTcNmAp & & \\
\hline SuCmAp & & \\
\hline $\mathrm{SuCm}$ & & \\
\hline Tc & & \\
\hline SmSuCmTcSpc & (2) & \\
\hline SmSuCmSpc & (3) & \\
\hline SmSuTcSpc & (2) & \\
\hline $\mathrm{TcNm}$ & (2) & \\
\hline Tc & (8) & \\
\hline
\end{tabular}

* Sm, Streptomycin; Su, sulphonamide; $\mathrm{Cm}$, chloramphenicol; Tc, tetracycline; Spc, spectinomycin; $\mathrm{Nm}$, neomycin; Ap, ampicillin. The numbers of plasmids that mediated the resistance quoted are given in parentheses.

+ Classified as enterobacteria by their appearance on MacConkey agar.

\pm By the indirect method, which did not require the isolation of the $\mathbf{R}^{+}$donor organisms.

inoculum for this test consisting of approximately $10^{4}$ viable organisms $\mathrm{ml}^{-1}$ and the temperature and time of incubation being $37^{\circ} \mathrm{C}$ and $6 \mathrm{~d}$. A minimal salts agar medium, supplemented when necessary with growth factors, was used to detect utilization of lactose, sucrose and raffinose (Smith \& Parsell, 1975).

Pathogenicity tests. Each $\mathrm{R}^{+} S$. typhimurium strain was given orally to a group of six 1 d-old chicks in a dose of approximately $10^{9}$ viable organisms; the $R^{-}$strain was given to three groups. The chicks were observed daily for $16 \mathrm{~d}$. In an attempt to identify plasmids that synthesized lethal toxin, $0.5 \mathrm{ml}$ of a shaken Tryptic Soy Broth (Difco) culture containing $10^{9}$ viable organisms $\mathrm{ml}^{-1}$ was inoculated subcutaneously into two young adult white Swiss mice and two $4 \mathrm{~d}$-old chicks. The animals were observed daily for $5 \mathrm{~d}$.

\section{RESULTS}

Incidence of thermosensitivity in enterobacterial antibiotic resistance plasmids; the isolation of thermosensitive plasmids from sewage and river water

Of 775 antibiotic resistance plasmids in enterobacterial strains that had been isolated from healthy and diseased human beings and domestic animals or, by the direct method, from sewage and rivers, $24(3 \cdot 1 \%$ ) were thermosensitive (Table 1$)$. There was no association 


\section{Table 2. Transfer rate of $t s$ and $t$ plasmids at different temperatures}

Plasmids F, I and Sh. dysenteriae are $\mathrm{tt}$; the remainder are ts. Plasmids of groups $\mathrm{H} 1$ and $\mathrm{H} 2$ are marked as such. The plasmids were transferred from the $\mathrm{k} 12$ Proto strain to the $\mathrm{k} 12$ Auxo strain, and the ts plasmids were divided into two sets according to their degree of transfer at $33{ }^{\circ} \mathrm{C}$.

Plasmid

No.
$47(\mathrm{H} 2)$
$49(\mathrm{H} 2)$
$71(\mathrm{H} 2)$
$12(\mathrm{H} 2)$
$9(\mathrm{H} 2)$
$59(\mathrm{H} 2)$
$66(\mathrm{H} 2)$
$58(\mathrm{H} 2)$
$68(\mathrm{H} 2)$
$55(\mathrm{H} 2)$
87
$32(\mathrm{H} 2)$
$30(\mathrm{H} 1)$
$44(\mathrm{H} 1)$
Rts 1
S. typhi $14(\mathrm{H} 1)$
S. thompson
F
I
Sh. dysenteriae

Proportion of recipient organisms that acquired the plasmid at $\left({ }^{\circ} \mathrm{C}\right)$ :

\begin{tabular}{ccccc}
\hline 15 & 22 & 28 & 33 & \multicolumn{1}{c}{37} \\
$5 \times 10^{-3}$ & $1 \times 10^{-1}$ & $2 \times 10^{-2}$ & $1 \times 10^{-7}$ & $1 \times 10^{-7}$ \\
- & $2 \times 10^{-2}$ & $2 \times 10^{-3}$ & $<1 \times 10^{-7}$ & $<1 \times 10^{-7}$ \\
$3 \times 10^{-4}$ & $6 \times 10^{-2}$ & $9 \times 10^{-4}$ & $1 \times 10^{-7}$ & $<1 \times 10^{-7}$ \\
$9 \times 10^{-3}$ & $7 \times 10^{-2}$ & $3 \times 10^{-2}$ & $<1 \times 10^{-7}$ & $<1 \times 10^{-7}$ \\
$2 \times 10^{-3}$ & $1 \times 10^{-1}$ & $3 \times 10^{-3}$ & $1 \times 10^{-7}$ & $<1 \times 10^{-7}$ \\
$5 \times 10^{-4}$ & $5 \times 10^{-3}$ & $9 \times 10^{-5}$ & $<1 \times 10^{-7}$ & $<1 \times 10^{-7}$ \\
& & & & \\
$1 \times 10^{-4}$ & $4 \times 10^{-2}$ & $6 \times 10^{-3}$ & $3 \times 10^{-3}$ & $<1 \times 10^{-7}$ \\
$1 \times 10^{-2}$ & $2 \times 10^{-1}$ & $3 \times 10^{-2}$ & $2 \times 10^{-2}$ & $1 \times 10^{-5}$ \\
$2 \times 10^{-4}$ & $1 \times 10^{-2}$ & $1 \times 10^{-2}$ & $2 \times 10^{-3}$ & $<1 \times 10^{-7}$ \\
$4 \times 10^{-5}$ & $8 \times 10^{-3}$ & $2 \times 10^{-2}$ & $5 \times 10^{-3}$ & $1 \times 10^{-7}$ \\
- & $3 \times 10^{-4}$ & $1 \times 10^{-3}$ & $1 \times 10^{-3}$ & $<1 \times 10^{-6}$ \\
$1 \times 10^{-3}$ & $9 \times 10^{-2}$ & $6 \times 10^{-1}$ & $5 \times 10^{-1}$ & $2 \times 10^{-4}$ \\
- & $4 \times 10^{-3}$ & $3 \times 10^{-2}$ & $9 \times 10^{-3}$ & $<1 \times 10^{-7}$ \\
$1 \times 10^{-4}$ & $2 \times 10^{-1}$ & $1 \times 10^{-1}$ & $9 \times 10^{-2}$ & $<1 \times 10^{-7}$ \\
& & & & \\
$2 \times 10^{-4}$ & $5 \times 10^{-2}$ & $3 \times 10^{-1}$ & $3 \times 10^{-1}$ & $<1 \times 10^{-7}$ \\
$5 \times 10^{-5}$ & $4 \times 10^{-2}$ & $7 \times 10^{-2}$ & $6 \times 10^{-2}$ & $<1 \times 10^{-7}$ \\
$1 \times 10^{-1}$ & $8 \times 10^{-1}$ & $7 \times 10^{-1}$ & $2 \times 10^{-3}$ & $<1 \times 10^{-7}$ \\
& & & & \\
$1 \times 10^{-7}$ & $1 \times 10^{-6}$ & $6 \times 10^{-3}$ & $3 \times 10^{-1}$ & $7 \times 10^{-1}$ \\
$6 \times 10^{-6}$ & $1 \times 10^{-3}$ & $1 \times 10^{0}$ & $1 \times 10^{0}$ & $9 \times 10^{-1}$ \\
$1 \times 10^{-6}$ & $1 \times 10^{-6}$ & $3 \times 10^{-4}$ & $9 \times 10^{-2}$ & $2 \times 10^{-2}$
\end{tabular}

between ts plasmids and any disease condition or any animal species. Three of the eight laboratory strains of Klebsiella pneumoniae were ts. Three of the eleven enterobacterial strains from sewage or rivers found to possess ts plasmids also belonged to this species; two others were $E$. coli, two Citrobacter spp. and four were taxonomically anomalous. When examined by the enrichment technique, ts plasmids were found in all the samples of sewage and river water that were examined. Of the 73 ts plasmids identified in this survey, 41 determined resistance to at least four antibiotics and 39 determined resistance to chloramphenicol, in addition to other antibiotics. Genes mediating chloramphenicol resistance were common amongst ts and tt (thermotolerant) plasmids in enterobacterial strains in sewage and river water. For example, although in the direct method of examining river water, organisms were picked as being potentially $\mathrm{R}^{+}$because they were resistant to ampicillin, streptomycin, neomycin, tetracycline or chloramphenicol, 95 out of 133 that were ultimately proved to be $\mathrm{R}^{+}$possessed resistance determinants that included those mediating chloramphenicol resistance.

Twelve of the 73 ts plasmids belonged to compatibility group $\mathrm{H} 1$. One was $\mathrm{SuCmAp}{ }^{+}$, one $\mathrm{SuCm}^{+}$, two $\mathrm{TcNm}^{+}$and eight $\mathrm{Tc}^{+}$. Ten had been obtained by the enrichment method (four from sewage and six from river water) and two, both $\mathrm{Tc}^{+}$, had been found in $E$. coli isolated from the faeces of healthy pigs. Of the remaining 61 plasmids, 58 belonged to group $\mathrm{H} 2$ and three belonged neither to this group nor to $\mathrm{H} 1$. The three that belonged to neither group comprised an $\mathrm{Ap}^{+}$plasmid found in an E. coli strain from the faeces of a healthy pig, another $\mathrm{Ap}^{+}$plasmid found in a Salmonella cholerae-suis strain and an $\mathrm{ApSm}^{+}$plasmid that had been found in an E. coli strain from river water. 
Table 3. Rate of loss of ts plasmids during daily passage in broth at different temperatures of the $\mathrm{K} 12$ Proto strain in which they had been implanted

Between 30 and 100 colonies from each culture were examined for plasmid loss.

\begin{tabular}{|c|c|c|c|c|c|c|c|}
\hline \multirow[b]{3}{*}{ Plasmid no. } & \multicolumn{7}{|c|}{ Percentage loss after the number of passages indicated at: } \\
\hline & \multirow{2}{*}{$\begin{array}{l}37^{\circ} \mathrm{C} \\
\text { three }\end{array}$} & \multicolumn{2}{|c|}{$40^{\circ} \mathrm{C}$} & \multicolumn{2}{|c|}{$42^{\circ} \mathrm{C}$} & \multicolumn{2}{|c|}{$44^{\circ} \mathrm{C}$} \\
\hline & & one & three & one & three & one & three \\
\hline 87 & 0 & 2 & 8 & 7 & 9 & 52 & 100 \\
\hline 17 & 7 & 3 & 66 & 3 & 55 & 6 & 88 \\
\hline 19 & 3 & 0 & 14 & 4 & 25 & 0 & 50 \\
\hline 12 & 0 & 0 & 0 & 1 & 1 & 12 & 45 \\
\hline 6 & 0 & 0 & 0 & 0 & 6 & 0 & 2 \\
\hline Rts 1 & 0 & 2 & 63 & 82 & 90 & 100 & 100 \\
\hline S. typhi $14(\mathrm{H} 1)$ & 0 & 一 & 一 & - & 一 & 0 & 3 \\
\hline S. thompson & 0 & 一 & - & 一 & - & 0 & 2 \\
\hline
\end{tabular}

Transfer rate of ts plasmids at different temperatures

The transfer rate of all 73 ts plasmids was estimated at $22,28,33$ and $37^{\circ} \mathrm{C}$; that of 19 of them was also estimated at $15^{\circ} \mathrm{C}$. The results obtained for a selection of them are summarized in Table 2. Those for three 'stock' ts plasmids [Rts 1 of Terawaki et al. (1967), a plasmid from the Vietnamese S. typhi 14 strain of Butler et al. (1973) and a plasmid from the Salmonella thompson strain of Smith \& Parsell (1975)] and three tt plasmids [F, Idrd16 of Hardy et al. (1973) and a group O plasmid from a Shigella dysenteriae strain isolated by Datta \& Olarte (1974)] are included for comparison. According to their pattern of transfer at the different temperatures, the 73 ts plasmids were divided into two sets. Set 1 comprised 16 plasmids that transferred best at $22{ }^{\circ} \mathrm{C}$ and poorly or not at all at $33{ }^{\circ} \mathrm{C}$ and above, and set 2 comprised 57 plasmids that transferred best at 22,28 and $33{ }^{\circ} \mathrm{C}$ and poorly or not at all at $37^{\circ} \mathrm{C}$ and above; all 19 plasmids studied at $15^{\circ} \mathrm{C}$ transferred less efficiently at that temperature than at $22^{\circ} \mathrm{C}$. Differences were found between the transfer rate patterns of some of the plasmids in set 2 but they did not appear sufficient to merit further sub-division. The plasmids in set 1 had all been obtained from sewage or river water. All 16 mediated chloramphenicol resistance (six were $\mathrm{SmSuCmTcSpc}^{+}$and ten $\mathrm{SmSuCmSpc}^{+}$) whereas only 23 of the 57 set 2 plasmids did so; the $23 \mathrm{Tc}^{+}$plasmids all belonged to set 2 . The $12 \mathrm{H} 1$ plasmids, the three plasmids whose incompatibility group was not known, and the H1 S. typhi 14 plasmid were in set 2 as were Rts 1 and the $S$. thompson plasmid; $\mathrm{H} 2$ plasmids were in both sets, and comprised all those in set 1 .

In general, the $12 \mathrm{H} 1$ plasmids transferred as efficiently as the S. typhi 14 plasmid and the $\mathrm{H} 2$ plasmids. At $22^{\circ} \mathrm{C}$, two of the $\mathrm{H} 1$ plasmids and three $\mathrm{H} 2$ plasmids of set 1 , the only plasmids tested, transferred from the $\mathrm{K} 12$ Proto strain to a $\mathrm{Vi}^{+}$strain of $S$. typhi at a rate of $10^{-1}$, the same rate at which the $S$. typhi $14 \mathrm{H} 1$ plasmid transferred.

In contrast to the ts plasmids, the three tt plasmids transferred very efficiently at the higher temperatures and much less efficiently at the lower ones, the temperature effect being especially noticeable with $\mathrm{F}$ and the $S h$. dysenteriae plasmid.

\section{Plasmid loss during incubation at high temperatures}

After three daily passages in broth at $44{ }^{\circ} \mathrm{C}$, no plasmid loss was detected from forms of the $\mathrm{K} 12$ Proto strain in which 34 of the 73 ts plasmids had been implanted. The rate of loss from 12 forms was 1 to $3 \%$, of 9 forms was 4 to $10 \%$, of 11 forms was 11 to $30 \%$ and of 7 forms was 31 to $100 \%$. In general, set 1 plasmids were lost faster than set 2 plasmids. The rate of loss of $\mathrm{Hl}$ plasmids was always small. Four of the $\mathrm{R}^{+}$forms that had suffered 


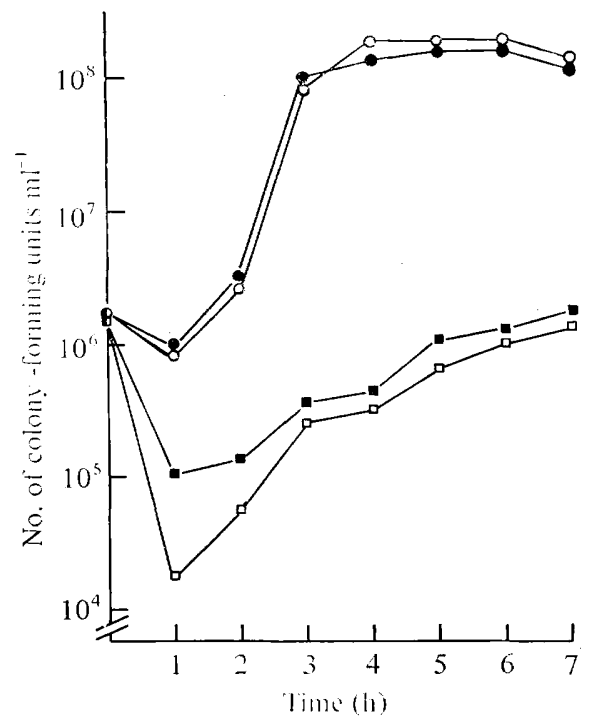

Fig. 1. The growth rate of different $\mathrm{R}^{+}$forms of $E$. coli $\mathrm{K} 12$ Proto in $0.03 \%$ sodium lauryl sulphate broth at $42^{\circ} \mathrm{C}$ : $\mathrm{O}$, E. coli $\mathrm{K} 12$ Proto;, E. coli $\mathrm{K} 12$ Proto $\mathrm{R} 8^{+} ; \mathbf{\square}$, E. coli $\mathrm{K} 12$ Proto Rts $1^{+}$; $\square$, E. coli $\mathrm{K} 12$ Proto $\mathrm{R} 37^{+}$.

the greatest rate of plasmid loss and one that had suffered only a slight loss were re-examined after one or three passages at $37,40,42$ and $44{ }^{\circ} \mathrm{C}$; their rate of plasmid loss was never as great as that of Rts 1 (Table 3 ).

Because some of the plasmids could have lost conjugative ability but not their resistance determinants in the passage experiments, 48 of the $\mathrm{R}^{+} \mathrm{K} 12$ Proto forms which had suffered no loss or a very low rate of loss were re-passaged three times at $44{ }^{\circ} \mathrm{C}$ and 10 isolates from each were tested for ability to transfer their determinants. None of the 10 isolates from each of 45 strains had lost conjugative ability, but seven of one and one each of another two strains had done so.

Thirteen tt plasmids found in sewage or river water were also examined for thermostability by submitting cultures of forms of the $\mathrm{k} 12$ Proto strain in which they had been implanted to three daily passages at $44^{\circ} \mathrm{C}$. As a group, they were lost at a rather higher rate than the ts plasmids.

\section{Effect of the ts plasmids on the growth of the K12 Proto strain in sodium lauryl sulphate broth}

All the forms of the $\mathrm{K} 12$ Proto strain in which one of 72 of the ts plasmids had been implanted grew at the same rate as the $\mathrm{R}^{-}$Proto strain in $0.03 \%$ sodium lauryl sulphate broth at $42{ }^{\circ} \mathrm{C}$. The growth of the remaining form $\left(\mathrm{R} 37^{+}\right)$which was harbouring an $\mathrm{H} 2$ plasmid of set 2 was inhibited as markedly as that of a form harbouring the Rts 1 plasmid, but both forms suffered a sharp initial decrease in colony-forming organisms (Fig. 1).

\section{Resistance to inorganic compounds mediated by the ts plasmids}

Sodium arsenite. By strip diffusion tests, $28(38.4 \%)$ of the $73 \mathrm{R}^{+}$forms of the S. typhimurium strain were classified as resistant and 45 as sensitive. The minimum inhibitory concentration (m.i.c.) of sodium arsenite for the resistant forms was 250 to $2000 \mu \mathrm{g} \mathrm{ml}^{-1}$ (median, $2000 \mu \mathrm{g} \mathrm{ml}^{-1}$ ) and was $<30 \mu \mathrm{g} \mathrm{ml}^{-1}$ for the sensitive forms and for the $\mathrm{R}^{-}$parent strain.

Mercuric chloride. The m.i.c. of mercuric chloride for $39(53.4 \%)$ of the $\mathrm{R}^{+}$forms of strain 
$\mathrm{K} 12$ Proto classed as resistant by strip diffusion tests was 32 to $128 \mu \mathrm{g} \mathrm{ml}^{-1}$ (median $32 \mu \mathrm{g}$ $\mathrm{ml}^{-1}$ ) and was $8 \mu \mathrm{g} \mathrm{ml}^{-1}$ for the 43 classed as sensitive and the $\mathrm{R}^{-}$parent strain.

Potassium tellurite. The m.i.c. of potassium tellurite for $58(79.5 \%)$ of the $\mathrm{R}^{+}$forms of strain $\mathrm{K} 12$ Proto classed as resistant by strip diffusion tests was 32 to $128 \mu \mathrm{g} \mathrm{ml}^{-1}$ (median $64 \mu \mathrm{g} \mathrm{ml}^{-1}$ ) and for the 15 classed as sensitive and the $\mathrm{R}^{-}$parent strain was $4 \mu \mathrm{g} \mathrm{ml}^{-1}$.

Other compounds. Apart from five plasmids which mediated a slightly increased resistance to cobalt nitrate, all 73 plasmids were shown in strip diffusion tests not to mediate resistance to this compound, silver nitrate or copper sulphate.

A high proportion of the plasmids that mediated resistance to chloramphenicol in addition to other antibiotics, including all 16 in set 1 , also mediated resistance to mercury, arsenite and tellurite whereas none of the $\mathrm{Cm}^{-}$ones did. Plasmids that were $\mathrm{Tc}^{+}$only either mediated resistance to tellurite only or to none of the three compounds. Apart from one that mediated mercury resistance, none of the $12 \mathrm{H} 1$ plasmids, the $S$. typhi $\mathrm{H} 1$ plasmid or the Rts 1 plasmid mediated resistance to any of the compounds. Of the six plasmids found in $K$. pneumoniae and which mediated resistance to chloramphenicol in addition to other antibiotics, all were resistant to mercury, arsenite and tellurite.

Because of the close association between chloramphenicol and mercury resistance in the ts plasmids, 357 wild-type $E$. coli strains known to possess tt plasmids mediating resistance to chloramphenicol in addition to other antibiotics were examined and $316(88 \%)$ were found to be mercury resistant. All forms of the $S$. typhimurium recipient strain to which the plasmids of 50 of the mercury-resistant strains were transferred had also acquired mercury resistance; none of the forms were arsenite- or tellurite-resistant.

\section{Substrate utilization by the ts plasmids}

None of the forms of the $\mathrm{k} 12$ Proto strain in which one of the 73 ts plasmids had been implanted utilized raffinose as sole energy source. Three of the six forms harbouring the K. pneumonide ts plasmids utilized lactose (when implanted in the lac K12 Auxo strain) and two, one from sewage and one from river water, utilized sucrose; the plasmids for sucrose utilization also mediated use of raffinose when present in the S. typhimurium strain but not when they were in the K12 Proto strain.

Forms of strain K12 Proto harbouring three of the twelve $\mathrm{Hl}$ plasmids and the H1 plasmid from the $S$. typhi 14 strain, but none of the other plasmids, utilized citrate as sole energy source. The three $\mathrm{Cit}^{+}$plasmids had been obtained by the enrichment method from sewage; two were $\mathrm{TcNm}^{+}$and one was $\mathrm{Tc}^{+}$.

The properties of the 73 thermosensitive plasmids are summarized in Table 4.

\section{Mediation of pathogenicity by the $t$ s plasmids}

Either none or one death occurred in each of the groups of six chicks inoculated orally with one of the $73 \mathrm{R}^{+}$forms of the $S$. typhimurium strain; two of 18 died in the group given the $\mathrm{R}^{-}$form. No signs of ill-health were noted in groups of two mice and four chicks inoculated intramuscularly with $0.5 \mathrm{ml}$ of Tryptic Soy Broth cultures of each of the $73 \mathrm{R}^{+}$ forms of the $\mathrm{K} 12$ Proto strain.

\section{Mediation of other characteristics by the ts plasmids}

None of the 73 forms of the K12 Proto strain that were harbouring different ts plasmids produced colicin, haemolysin or urease; neither did they liquefy gelatin or produce hydrogen sulphide. The appearance of cultures of these forms and of the corresponding forms of the $S$. typhimurium strain in broth and on nutrient and MacConkey agar resembled those of cultures of the $\mathrm{R}^{-} \mathrm{K} 12$ Proto or $S$. typhimurium parent strains. None of the $\mathrm{R}^{+}$forms were lysogenic for the $\mathrm{R}^{-}$parent. 
Table 4. Properties of thermosensitive plasmids

\begin{tabular}{|c|c|c|c|c|c|c|c|c|c|c|c|c|}
\hline $\begin{array}{l}\text { No. of } \\
\text { plasmids }\end{array}$ & $\begin{array}{l}\text { Incom- } \\
\text { patibility } \\
\text { group }\end{array}$ & $\begin{array}{l}\text { Antibiotic } \\
\text { resistances } \\
\text { mediated }\end{array}$ & $\begin{array}{l}\operatorname{Re} \\
\text { med } \\
\text { asi }\end{array}$ & $\begin{array}{l}\text { sistar } \\
\text { liated } \\
\text { mer }\end{array}$ & & lac & $\underbrace{\text { Utili }}_{\text {suc }}$ & & & $\begin{array}{l}\text { High } \\
\text { trans- } \\
\text { mission } \\
\text { rate at } \\
33{ }^{\circ} \mathrm{C}\end{array}$ & $\begin{array}{c}\text { Unstable } \\
\text { in host } \\
\text { at } 44^{\circ} \mathrm{C}\end{array}$ & $\begin{array}{c}\text { Inhibited } \\
\text { multipli- } \\
\text { cation } \\
\text { of host }\end{array}$ \\
\hline 1 & H1 & SuCmAp & - & - & - & - & - & - & - & + & + & - \\
\hline 1 & H1 & $\mathrm{SuCm}$ & - & + & - & - & - & - & - & + & + & - \\
\hline 1 & $\mathrm{H} 1$ & $\mathrm{TcNm}$ & - & - & - & - & - & - & + & + & - & - \\
\hline 1 & $\mathrm{H} 1$ & $\mathrm{TcNm}$ & - & - & - & - & - & - & + & + & + & - \\
\hline 1 & H1 & $\mathrm{Tc}$ & - & - & - & - & - & - & + & + & + & - \\
\hline 1 & H1 & $\mathrm{Tc}$ & - & - & - & - & - & - & - & + & - & - \\
\hline 6 & H1 & $\mathrm{Tc}$ & - & - & - & - & - & - & - & + & + & - \\
\hline 1 & $\mathrm{H} 2$ & $\mathrm{SmSuCmTcSpcNmAp}$ & - & - & + & - & - & - & - & + & - & - \\
\hline 2 & $\mathrm{H} 2$ & SmSuCmTcSpcNm & - & + & + & - & - & - & - & + & - & - \\
\hline 2 & $\mathrm{H} 2$ & SmSuCmTcSpc & + & + & + & - & + & + & - & - & - & - \\
\hline 1 & $\mathrm{H} 2$ & SmSuCmTcSpc & + & + & + & - & - & - & - & - & - & - \\
\hline 3 & $\mathrm{H} 2$ & $\mathrm{SmSuCmTcSpc}$ & + & + & + & - & - & - & $\rightarrow$ & - & + & - \\
\hline 2 & $\mathrm{H} 2$ & SmSuCmTcSpc & + & + & + & + & - & - & - & + & - & - \\
\hline 1 & $\mathbf{H} 2$ & $\mathrm{SmSuCmTcSpc}$ & + & + & + & + & - & - & - & + & + & - \\
\hline 2 & $\mathrm{H} 2$ & SmSuCmTcSpc & + & + & + & - & - & - & - & + & - & - \\
\hline 1 & $\mathrm{H} 2$ & SmSuCmTcSpc & + & + & + & - & - & - & - & + & + & - \\
\hline 10 & $\mathrm{H} 2$ & SmSuCmSpc & + & + & + & - & - & - & - & - & + & - \\
\hline 5 & $\mathrm{H} 2$ & $\mathrm{SmSuCmSpc}$ & + & + & + & - & - & - & - & + & - & - \\
\hline 1 & $\mathrm{H} 2$ & SmSuCmSpc & - & + & + & - & - & - & - & + & - & - \\
\hline 3 & $\mathrm{H} 2$ & SmSuCmSpc & - & + & + & - & - & - & - & + & + & - \\
\hline 1 & $\mathrm{H} 2$ & SmSuCmTcAp & - & + & + & - & - & - & - & + & - & - \\
\hline 1 & $\mathrm{H} 2$ & SmSuCm & + & + & + & - & - & - & - & + & - & - \\
\hline 1 & $\mathrm{H} 2$ & $\mathrm{SmCmTc}$ & - & - & + & - & - & - & - & + & - & - \\
\hline 2 & $\mathrm{H} 2$ & SmSuTcSpc & - & + & + & - & - & - & - & + & + & - \\
\hline 1 & $\mathrm{H} 2$ & $\mathrm{SmSuTcSpc}$ & - & - & + & - & - & - & - & + & - & - \\
\hline 1 & $\mathrm{H} 2$ & SmSuTcSpc & - & + & - & - & - & - & - & + & + & - \\
\hline 2 & $\mathrm{H} 2$ & SmTcNmAp & - & - & + & - & - & - & - & + & + & - \\
\hline 12 & $\mathrm{H} 2$ & $\mathrm{Tc}$ & - & - & + & - & - & - & - & + & - & - \\
\hline 2 & $\mathrm{H} 2$ & $\mathrm{Tc}$ & - & - & + & - & - & - & - & + & + & - \\
\hline 1 & $\mathrm{H} 2$ & Tc & - & - & + & - & - & - & - & + & + & + \\
\hline 1 & $\begin{array}{c}\text { Not } \mathrm{H} 1 \\
\text { or } \mathrm{H} 2\end{array}$ & SmAp & - & - & - & - & - & - & - & + & + & - \\
\hline 1 & $\begin{array}{c}\text { Not } \mathrm{H} 1 \\
\text { or } \mathrm{H} 2\end{array}$ & Ap & - & - & + & - & - & - & - & + & + & - \\
\hline 1 & $\begin{array}{c}\text { Not } \mathrm{H} 1 \\
\text { or } \mathrm{H} 2\end{array}$ & Ap & - & - & - & - & - & - & - & + & + & - \\
\hline
\end{tabular}

asi, arsenite; mer, mercury; tel, tellurite; lac, lactose; suc, sucrose; raf, raffinose; cit, citrate.

\section{DISCUSSION}

As a group, the 73 ts plasmids, which were obtained from a wide variety of sources, differed markedly from Rts 1 , the ts plasmid that was first discovered and that has been most extensively studied (Terawaki et al., 1967). For example, following their implantation in the $\mathrm{K} 12$ Proto strain, only one of them, an $\mathrm{H} 2$ plasmid, markedly reduced the growth rate of this strain at $42{ }^{\circ} \mathrm{C}$. However, much of the reduction in the case of this and the Rts $1^{+}$form was really due to an initial sharp reduction in the numbers of colony-forming organisms. This would not be apparent when using photometric methods for measuring bacterial growth (Terawaki et al., 1967). Although instability in the $\mathrm{K} 12$ Proto strain at high temperatures was a feature of some of the plasmids, the incidence of this instability was no higher than in the group of tt plasmids that we examined. Neither was its degree sufficient to warrant their classification with Rts 1 as being thermosensitive for replication; they were solely or mainly thermosensitive for transfer. The incompatibility grouping results also 
indicate that plasmids of group $\mathrm{H} 2$ may be far more common than plasmids of group $\mathrm{T}$, the group to which Rts 1 belongs.

Although our ts plasmids always transferred at very low rates at $37^{\circ} \mathrm{C}$, or not at all, differences in transfer rate were sometimes noted when some of them were tested at one or other of the lower temperatures on more than one occasion. Their division into two sets according to degree of transfer at $33^{\circ} \mathrm{C}$, however, appeared to be a reliable one. It was supported by the finding that all the plasmids in set 1 provided resistance against chloramphenicol and several other antibiotics and against mercury, arsenite and tellurite whereas only some of those in set 2 did so. Also set 2 included all the $\mathrm{H} 1$ plasmids. Practically all the plasmids transferred at high rates at $22{ }^{\circ} \mathrm{C}$, environmental temperatures that prevail in many countries, thus making their transfer in voided excreta, sewage and polluted rivers a definite possibility. Transfer in the alimentary tract of homothermic animals, even with the selection pressure provided by antibiotics, seems less likely. In the conjugation experiments between $E$. coli $\mathrm{K} 12$ strains and between $E$. coli $\mathrm{K} 12$ and $S$. typhi, $\mathrm{H} 2$ plasmids transferred as efficiently as $\mathrm{H} 1$ plasmids at all temperatures. However, although we found that more of our ts plasmids, and especially those that mediated chloramphenicol resistance, belonged to group $\mathrm{H} 2$ than to group $\mathrm{H} 1$, all the strains examined from outbreaks of chloramphenicol resistant $S$. typhi in Mexico, Vietnam, Thailand and India harboured H1, not $\mathrm{H} 2$, plasmids (Anderson, 1975). Salmonella typhimurium strains mediating resistance to antibiotics other than chloramphenicol and causing disease in the Far East and the United Kingdom also harboured $\mathrm{H} 1$ plasmids (Anderson, 1975). If the relative distribution of $\mathrm{H} 1$ and $\mathrm{H} 2$ plasmids in countries in which outbreaks of disease caused by organisms harbouring ts plasmids is similar to that found in our survey, then $\mathrm{H} 1$ plasmids may well possess properties not shared with $\mathrm{H} 2$ plasmids that facilitate their conjugation with pathogenic enterobacteria in extra-intestinal situations, properties not brought to light in the present study. On the other hand, it may be that the relative distribution of $\mathrm{H} 1$ and $\mathrm{H} 2$ plasmids differs in different countries. It is noteworthy in this respect that Anderson (1975) found H2 plasmids in a chloramphenicol-resistant strain of $S$. typhi from a patient infected in Spain and in $S$. typhimurium strains isolated in Portugal, Belgium, Canada and Israel. Regarding the source of our $\mathrm{H} 1$ plasmids, it is of interest that two that mediated tetracycline resistance had been found in $E$. coli isolated from the faeces of pigs, a species which in the United Kingdom constitutes an enormous reservoir of tetracycline-resistant $E$. coli, the consequence of the past policy of continuously feeding them on diets containing tetracyclines for growth promotional purposes.

Our collection of $\mathrm{H} 1$ plasmids showed certain differences from the $\mathrm{H} 2$ collection. Only one of them mediated mercury resistance and none of them arsenite or tellurite resistance. More interestingly, they included three plasmids with citrate-utilizing ability which the present study has revealed to be yet another property that can be plasmid-mediated.

A high proportion of our ts plasmids mediated resistance to mercury, arsenite and tellurite; the mercury and arsenite resistance, but not the tellurite resistance, was largely confined to plasmids that provided resistance to chloramphenicol in addition to several other antibiotics. Mercury resistance is commonly associated with plasmids providing this kind of antibiotic resistance and was found in 316 of the $357 \mathrm{R}^{+}$wild-type $E$. coli strains we examined, in clinical isolates of $E$. coli and $K$. pneumoniae examined by Nakahara et al. $(1977 a, b)$ and in different kinds of enterobacteria and related bacteria examined by Joly \& Cluzel (1975). Plasmids mediating resistance to tellurite and arsenite may be less common than our survey of ts plasmids suggest. For example, none were found amongst the $50 \mathrm{tt}$ plasmids we examined. A lower incidence of tellurite and arsenate resistance was also found by Summers \& Jacoby (1977) during an examination of 'stock' plasmids of Pseudomonas aeruginosa and $E$. coli while Joly \& Cluzel (1975) did not find arsenate resistance plasmids in their study. In these two surveys and those of Nakahara et al. $(1977 a, b)$ the temperaturesensitive status of the plasmids was not determined. 
We are grateful to Dr P. M. Biggs, Mr. F. Phillips and Miss Susan Shaw for help and advice in a variety of ways.

\section{REFERENCES}

ANDERSON, E. S. (1975). The problem and implications of chloramphenicol resistance in the typhoid bacillus. Journal of Hygiene 74, 289-299.

Butler, T., Linh, N. N., Arnold, K. \& Pollack, M. (1973). Chloramphenicol-resistant typhoid fever in Vietnam associated with $\mathrm{R}$ factor. Lancet ii, 983.

Coetzee, J. N., Datta, N. \& Hedges, R. W. (1972). $\mathrm{R}$ factors from Proteus rettgeri. Journal of General Microbiology 72, 543-552.

Cruickshank, R. (1970). In Medical Microbiology, 11 th edn. Edited by R. Cruickshank. Edinburgh and London: F. \& S. Livingstone.

DATTA, N. \& OLARTE, J. (1974). R factors in strains of Salmonella typhi and Shigella dysenteriae isolated during epidemics in Mexico: classification by compatibility. Antimicrobial Agents and Chemotherapy 5, 310-317.

Grabow, W. O. K., Prozesky, O. W. \& Burger, J. S. (1975). Behaviour in a river and dam of coliform bacteria with transferable or nontransferable drug resistance. Water Research 9, $777-782$.

Hardy, K. G., Meynell, G. G., Dowman, J. E. \& SPRATT, B. G. (1973). Two major groups of colicin factors; their evolutionary significance. Molecular and General Genetics 125, 217-230.

Joly, B. \& CluZEL, R. (1975). The role of heavy metals and their derivatives in the selection of antibiotic-resistant gram-negative bacilli. Annales de Microbiologie 126B, 51-61.

Lederberg, J. \& LederberG, E. M. (1952). Replica plating and indirect selection of bacterial mutants. Journal of Bacteriology 63, 399-406.

McHugh, G. L., Moellering, R. C., Hopkins, C. C. \& Swartz, M. N. (1975). Salmonella typhimurium resistance to silver nitrate, chloramphenicol and ampicillin. Lancet i, 235-239.

Miles, A. A. \& MisRa, S. S. (1938). The estimation of the bactericidal power of blood. Journal of Hygiene 38, 732-749.

Nakahara, H., Ishikawa, T., Sarai, Y., Kondo, I., KozukUe, H. \& Mitsuhashi, S. $(1977 a)$. Mercury resistance and $\mathbf{R}$ plasmids in Escherichia col isolated from clinical lesions in Japan. Antimicrobial Agents and Chemotherapy 11, 999-1003.
Nakahara, H., Ishikawa, T., Sarai, Y., Kondo, I. \& Kozukue, H. (1977b). Mercury resistance and $\mathrm{R}$ plasmids in clinical isolates of Klebsiella pneumoniae. Zentralblatt für Bakteriologie, Parasitenkunde, Infektionskrankheiten und Hygiene 238, 51-58.

Rodriguez-Lemoine, V., JACOB, A. E., Hedges, R. W. \& DATTA, N. (1975). Thermosensitive production of their transfer systems by group $\mathrm{S}$ plasmids. Journal of General Microbiology 86, 111-114.

Sato, G., Kodama, H. \& Terakado, N. (1974). Detection of an $\mathbf{R}$ factor showing temperaturesensitive transfer in Salmonella typhimurium isolated from calves. Antimicrobial Agents and Chemotherapy 5, 541-543.

Smith, H. Williams (1973). Chloramphenicol resistance in Escherichia coli. Journal of Medical Microbiology 6, 347-350.

Smith, H. Williams (1974). Thermosensitive transfer factors in chloramphenicol-resistant strains of Salmonella typhi. Lancet ii, 281-282.

Smith, H. Williams (1977). Mobilization of nonconjugative tetracycline, streptomycin, spectinomycin and sulphonamide resistance determinants of Escherichia coli. Journal of General Microbiology 100, 189-196.

Smith, H. Williams \& Parsell, Z. E. (1975). Transmissible substrate-utilizing ability in enterobacteria. Journal of General Microbiology 87, 129-140.

Summers, A. O. \& JACOBY, G. A. (1977). Plasmiddetermined resistance to tellurium compounds. Journal of Bacteriology 129, 276-281.

Terawaki, Y., Takayasu, H. \& Akiba, T. (1967). Thermosensitive replication of a kanamycin resistance factor. Journal of Bacteriology 94, 687-690.

Terawaki, Y., Kishi, H. \& NaKaYA, R. (1975). Integration of R plasmid Rts 1 to the gal region of the Escherichia coli chromosome. Journal of Bacteriology 121, 857-862.

Yoshida, Y., Terawaki, Y. \& Nakaya, R. (1974). Temperature sensitive R plasmid originated from Salmonella typhimurium. Biochemical and Biophysical Research Communications 59, 361-369. 